\section{Irrigating Nursery Crops with Recycled Run-off: A Review of the Potential Impact of Pesticides on Plant Growth and Physiology}

\author{
Shital Poudyal ${ }^{1}$ and Bert M. Cregg ${ }^{1,2,3}$
}

\begin{abstract}
ADDITIONAL INDEX WORDs. herbicides, insecticides, nursery management, phytotoxicity

SUMMARY. Interest in capturing and reusing runoff from irrigation and rainfall in container nurseries is increasing due to water scarcity and water use regulations.

However, grower concerns related to contaminants in runoff water and other issues related to water safety are potential barriers to the adoption of water capture and reuse technologies. In this review, we discuss some of the key concerns associated with potential phytotoxicity from irrigating container nursery crops with recycled runoff. The concentration of pesticides in runoff water and retention ponds is orders of magnitude lower than that of typical crop application rates; therefore, the risk of pesticide phytotoxicity from irrigation with runoff water is relatively low. Nonetheless, some pesticides, particularly certain herbicides and insecticides, can potentially affect crops due to prolonged chronic exposure. Pesticides with high solubility, low organic adsorption coefficients, and long persistence have the greatest potential for crop impact because they are the most likely to be transported with runoff from container pads. The potential impact on plant growth or disruption of physiological processes differs among pesticides and sensitivity of individual crop plants. Growers can reduce risks associated with residual pesticides in recycled irrigation water by adopting best management practices (e.g., managing irrigation to reduce pesticide runoff, reducing pots spacing during pesticide application, use of vegetative filter strips) that reduce the contaminant load reaching containment basins as well as adopting remediation strategies that can reduce pesticide concentrations in recycled water.
\end{abstract}

$\mathrm{T}$ he increasing water demand is exacerbating water scarcity worldwide. A list of the top 10 global risk factors published by World Economic Forum indicated that inadequate water supply is the top risk factor in terms of impact and the eighth risk factor in terms of likelihood (World Economic Forum, 2015). Freshwater withdrawals are

Received for publication 4 Feb. 2019. Accepted for publication 13 May 2019.

Published online 5 August 2019.

Funding for this study was provided by USDA SCRI Clean WateR ${ }^{3}$-Reduce, Remediate, Recycle, grant number 2014-51181-22372; MSU Project GREEEN, and USDA Hatch Project MICL 02413

This paper is based on information presented during the Clean Wate $\mathrm{R}^{3}$ program sessions, held as part of the ASHS Annual Conference, 30 July to 3 Aug. 2018, in Washington, DC.

${ }^{1}$ Department of Horticulture, Michigan State University, 1066 Bogue Street, East Lansing, MI 48824

${ }^{2}$ Department of Forestry, Michigan State University, 408 Wilson Road, East Lansing, MI 48824

${ }^{3}$ Corresponding author. E-mail: cregg@msu.edu.

This is an open access article distributed under the CC BY-NC-ND license (https://creativecommons.org/ licenses/by-nc-nd/4.0/).

https://doi.org/10.21273/HORTTECH04302-19 mainly used for agriculture, accounting for $69 \%$ of global water withdrawal (Food and Agriculture Organization of the United Nations, 2014). Fischer et al. (2007) estimated that water requirements for irrigation will increase by $45 \%$ globally in the next 60 years.

Many parts of the United States are facing increasing drought severity and frequency. As a result, surface water sources are declining in many areas. For example, water flow in the Colorado River, which supplies water to $\approx 40$ million people, could diminish by $35 \%$ by 2050 (Johnson, 2013; Rajagopalan et al., 2009; Wines, 2014). With increasing drought and possible declines in water availability, horticultural producers need to find ways to improve irrigation efficiency, including reusing runoff for irrigation. In 2015, irrigation accounted for $37 \%$ of total water use in the United States (Maupin, 2018). Horticulture is a major sector of U.S. agriculture and it is expanding. In 2014 , sales of all horticultural crops in the United States were estimated to be $\$ 13.8$ billion, which was a $\$ 2$ billion increase from 2009 (U.S. Department of Agriculture, 2016). Ample irrigation is a crucial requirement for many horticultural crops, which has led to a continuous increase in water consumption since 2004 (Fulcher et al., 2016). In 2013, 556,490 of 661,862 acres $(84 \%)$ of horticulture operations were irrigated. These operations consumed 223 billion gallons of water, $65 \%$ of which was applied as overhead sprinkler irrigation (Vilsack and Reilly, 2013). Irrigation efficiency can be particularly low in container nursery production. In overhead irrigation systems, up to $80 \%$ of water applied may be lost as runoff, depending on container spacing and container size (Beeson and Knox, 1991; Mathers et al., 2005). However, overhead or sprinkler irrigation remains the most common, reliable, and economical method of irrigating plants. A common nursery recommendation is to schedule irrigation to achieve a $15 \%$

\begin{tabular}{lllc}
\hline $\begin{array}{l}\text { Units } \\
\begin{array}{l}\text { To convert U.S. to SI, } \\
\text { multiply by }\end{array}\end{array}$ & U.S. unit & SI unit & $\begin{array}{l}\text { To convert SI to U.S., } \\
\text { multiply by }\end{array}$ \\
\hline 0.4047 & acre(s) & $\mathrm{ha}$ & $2.471 \mathrm{l}$ \\
73.0778 & $\mathrm{fl} \mathrm{oz} / \mathrm{acre}$ & $\mathrm{mL} \cdot \mathrm{ha}^{-1}$ & 0.0137 \\
3.7854 & gal & $\mathrm{L}$ & 0.2642 \\
2.54 & inch(es) & $\mathrm{cm}$ & 0.3937 \\
25.4 & inch $(\mathrm{es})$ & $\mathrm{mm}$ & 0.0394 \\
1.1209 & $\mathrm{lb} / \mathrm{acre}$ & $\mathrm{kg} \cdot \mathrm{ha}^{-1}$ & 0.8922 \\
1 & $\mathrm{mmh} / \mathrm{cm}$ & $\mathrm{dS} \cdot \mathrm{m}^{-1}$ & 1 \\
0.1333 & $\mathrm{~mm} \mathrm{Hg}$ & $\mathrm{kPa}$ & 7.5006 \\
70.0532 & $\mathrm{oz} / \mathrm{acre}$ & $\mathrm{g} \cdot \mathrm{ha}^{-1}$ & 0.0143 \\
1 & $\mathrm{ppb}$ & $\mu \cdot \mathrm{L}^{-1}$ & 1 \\
0.001 & $\mathrm{ppm}$ & $\mathrm{g} \cdot \mathrm{L}^{-1}$ & 1000 \\
1 & $\mathrm{ppm}$ & $\mathrm{mg} \cdot \mathrm{L}^{-1}$ & 1 \\
0.001 & $\mathrm{ppm}$ & $\mathrm{mL} \cdot \mathrm{L}^{-1}$ & 1000 \\
1 & $\mathrm{ppt}$ & $\mathrm{pg} \cdot \mathrm{L}^{-1}$ & 1 \\
2.3385 & $\mathrm{qt} / \mathrm{acre}$ & $\mathrm{L} \cdot \mathrm{ha}^{-1}$ & 0.4276 \\
& & &
\end{tabular}


leaching fraction (i.e., 15\% of applied irrigation is leached through the bottom of containers). Allowing a portion of irrigation water to flow out of containers prevents the buildup of soluble salts in the container substrate. However, growers' application practices are often more liberal, such as applying 0.75 inches of irrigation per day, resulting in significant overwatering and runoff (Bailey et al., 1999; Warsaw et al., 2009).

\section{Increased interest in water capture and reuse in nurseries}

Container nursery production is one of the most intensive agricultural systems in terms of resource inputs. Nurseries produce high-value specialty crops within a relatively short period. To produce marketable plants and reduce the risk of crop failure, growers rely heavily on irrigation, fertilizers, and pesticides. This can lead to significant losses of nitrogen $(\mathrm{N})$, phosphorus $(\mathrm{P})$, and potassium $(\mathrm{K})$ through runoff (Andersen and Hansen, 2000; Broschat, 1995; Colangelo and Brand, 2001). Elevated concentrations of $\mathrm{N}$ and $\mathrm{P}$ in water can cause eutrophication, dead zones, and algal blooms (Conley et al., 2009; National Oceanic and Atmospheric Administration, 2017). Pesticide runoff in nursery production is also a common concern (Mangiafico et al., 2008, 2009). A 10-year survey of major streams and groundwater found that $97 \%$ of stream water and $61 \%$ of shallow groundwater near agricultural areas had one or more pesticides present (Gilliom et al., 2006). Pesticides, even at low concentrations, may be detrimental to aquatic and terrestrial life. With rising water scarcity and increasing water pollution, the U.S. Environmental Protection Agency and state and local regulatory agencies are limiting groundwater withdrawals for agriculture and, in some cases, mandating runoff capture and reuse (Beeson et al., 2004; Fulcher et al., 2016). Moreover, regulations aimed at reducing fertilizer and pesticide runoff will likely increase (Lin et al., 2009). With this changing scenario, the nursery industry is obliged to consume less fresh water (Fulcher et al., 2016) and find ways to capture and reuse nursery runoff.

\section{Examples of water capture and recycling in nurseries}

Capturing runoff water on-site in a containment or retention pond is often the best way to prevent potential environmental problems associated with nursery runoff (Fain et al., 2000). In nurseries that capture runoff, collected water may be recycled to irrigate plants, either with or without treatment. Capturing and recycling nursery runoff water protects water sources, reduces water costs, and provides a constant water supply (Wilson and von Broembsen, 2015). The initial investment costs to build recycled water systems can be high, but they are often subsidized by various agencies, which can offset those costs within a few years. For example, a major nursery in California was able to recover the cost of a water recycling system within 1 year based on savings associated with purchasing less water (Pitton et al., 2018). Therefore, more nurseries are capturing and recycling runoff water. In a survey of 24 greenhouses and nurseries across 11 states, it was found that nurseries met $33 \%$ of their daily water requirement during peak irrigation demand using recycled water (Meador et al., 2012). In a survey of 65 nurseries in Ventura County, California, the number of nurseries collecting runoff doubled in just 2 years (from 2004 to 2006), indicating a rapid adoption rate of runoff capture (Mangiafico et al., 2010). In a recent survey of 60 nursery and greenhouse producers in Virginia, 51 (77\%) said that they would capture and collect runoff water (Mack et al., 2017). Similarly, in a 1998 survey of 24 nurseries on the Alabama coastline, $75 \%$ of the nurseries captured runoff in some way (Fain et al., 2000). Larger nurseries recycled $68 \%$ of total water applied, whereas smaller nurseries, if they had a recycling pond, recycled $98 \%$ of their water (Fain et al., 2000). Of 58 west-central Florida nurseries surveyed in a workshop in 2000,20 reported collecting runoff (Gisele et al., 2006). Similarly, a survey of 192 nursery growers across the United States indicated that $43 \%$ used water from retention ponds as a source of irrigation but were still concerned about the water quality (White et al., 2013).

\section{Concerns about crop safety}

Capturing and reusing nursery runoff can assure water security for nurseries and protect water resources, but safety in terms of crop health is a concern for growers. This hinders the adoption of water capturing and recycling technologies. Potential problems with irrigating nursery crops with runoff include water quality, introduction (or reintroduction) of fungal pathogens, and potential damage to crops from contaminants, particularly pesticides that may be present in runoff. Issues associated with pathogens in recycled water are discussed elsewhere in this issue (Parke et al., 2019). In this review, we consider the potential for pesticides in runoff to impact the growth and physiology of nursery crops.

WATER QUALITY. Maintaining water quality is crucial for nursery producers. Electrical conductivity (EC), $\mathrm{pH}$, and alkalinity are major factors when determining irrigation water quality; however, these factors may fluctuate in containment ponds. Nursery runoff water may have higher $\mathrm{pH}, \mathrm{EC}$, and alkalinity than recommended (Lu et al., 2006a; Zhang and Hong, 2017). This may be due to the leaching of soluble salts from containers or microbial activities in the pond. A study evaluating water quality of runoff flowing to nine different containment basins showed that $\mathrm{pH}$ of runoff was usually higher than the recommended $\mathrm{pH}$ of 6.8 (Copes et al., 2017). In a study of nutrients leaching at different irrigation and fertilizer rates, EC levels often fluctuated in the leachate and were occasionally higher than $1 \mathrm{dS} \cdot \mathrm{m}^{-1}$, which is slightly higher than the recommended rate $\left(<\mathrm{l} \mathrm{dS} \cdot \mathrm{m}^{-1}\right)$ for irrigation water (Million et al., 2007; Will and Faust, 2010).

Pathogens (Diseases). Pathogens are usually the main concern when managing nursery runoff water. The presence of pathogens even in one production area can infest an entire collection pond; if water from the infected ponds is reused, then inoculum can spread over an entire nursery. Plant pathogens are frequently detected in nursery runoff water and collection ponds (Bush et al., 2003; Ghimire et al., 2011; Junker et al., 2016; MacDonald, 1994; Pottorff and Panter, 1997; 
Werres et al., 2007), but this does not always translate to the infection of plant material. Along with reusing contaminated nursery runoff water, reuse of dirty pots, lack of proper drainage, and contact of pots with contaminated ground are the most common reasons for the spread of pathogens such as Phytophthora species and Pythium species (Kong and Richardson, 2004; Parke et al., 2008).

Pesticides. Apart from water quality and diseases, growers are also concerned about pesticides when considering the reuse of runoff water. Parween et al. (2016) extensively evaluated the effects of pesticides on grasses and agronomic crops. In this review, we evaluated how nursery crops are impacted by the presence of residual pesticides in irrigation water. Most of the research reviewed relates to nursery production; however, when information was limited, we reviewed other related agricultural production systems.

When pesticides are applied in container nurseries, wide plant spacing may result in pesticide deposition in nontarget areas between the plant containers. For example, in a study of methiocarb application efficiency on weeping fig (Ficus benjamina) and lady palm (Rhapis excelsa), $16 \%$ to $30 \%$ of pesticide granules landed in the spaces between containers (Wilson et al., 2005). Subsequent overhead irrigation can carry pesticides in runoff that is ultimately captured in retention ponds. Pesticide runoff has been reported in various nursery operations (Keese et al., 1994; Riley, 2003; Wilson et al., 1996). In a study by Gilliam et al. (1992), 80\% of applied granular herbicide landed off-target when empty 2.8 - $\mathrm{L}$ containers were spaced $30 \mathrm{~cm}$ apart. Typically, only a small fraction of pesticides leach out of containers because of high pesticide retention properties, particularly adsorption, of most soilless substrates. Hence, the largest portion of pesticide runoff is due to pesticide application to nontarget areas (Roseth and Haarstad, 2010). Properties of pesticides such as solubility, volatility, and adsorption as well as nursery management practices such as irrigation method and timing, crop spacing, and groundcover determine the quantity of pesticides in runoff water that eventually reach retention ponds. Briggs et al. (1998a) found isoxaben, thiophanate-methyl, trifluralin, and chlorpyrifos in runoff water from container production systems. Species vary in their sensitivity to pesticides (i.e., a pesticide safe for one species may be potentially detrimental for other species); therefore, plant sensitivity should be considered when decisions related to water recycling are made (Baz and Fernandez, 2002; Fernandez et al., 1999; Lu et al., 2006b; Moorman, 2011; Straw et al., 1996). Some of the common pesticides found in runoff water and retention ponds, along with their concentrations, are listed in Table 1.

\section{Pesticides used in nursery production and potential for crop damage}

In general, pesticides are compounds designed to control pests that damage crops. In nursery crops, the most widely used pesticides are herbicides, insecticides, and fungicides. Nematicides and rodenticides may also be applied in certain cases. Pesticides are usually carbon-based compounds that have functional groups that target specific sites in animal and/or plant metabolism to kill or inhibit their performance.

Herbicides. Herbicides are often the greatest concern among contaminants in nursery runoff because the pesticide target and crop are the same type of organism (plants). Herbicides can be pre-emergence or postemergence. Pre-emergence herbicides are commonly used in container nurseries and are applied to prevent seed germination and weed emergence. Postemergence herbicides are used to kill established weeds. If used on container plants, then many postemergent herbicides may injure established crop plants along with target weeds; hence, they are rarely applied in containers except to control weeds in noncrop areas such as walkways, aisles, and ditches (Atland, 2014; Robbins and Boyd, 2011).

The mode of action refers to the specific mechanisms by which herbicides kill or suppress weeds. More than 20 different modes of action have been documented for commercially available herbicides (Duke and Dayan, 2015); of those, herbicides with six different modes of action are commonly used in nurseries (Table 2) (Robbins and Boyd, 2011). The site of action is more specific and defines specifically where an herbicide has an impact (Table 2). For example, the mode of action of oxyfluorfen is cell membrane disruption, and its site of action is protoporphyrinogen oxidase (PPO) inhibition (Ross and Childs, 1996; University of Wisconsin, 2013).

Insecticides. Although the mode of action of insecticides targets insect metabolism, some insecticides can affect plants as well. Insecticides can reduce plant growth, mainly by inhibiting chlorophyll formation and interfering with photosynthetic reactions (Mishra et al., 2008; Parween et al., 2011a, 2011b, 2012). Chlorpyrifos, a commonly used insecticide, can alter chlorophyll concentration, affect leaf sugar content, inhibit chlorophyll formation, and degrade chlorophyll (Parween et al., 201la, 2011 b; Prasad et al., 2015). Insecticides belonging to the pyrethroid family and organophosphate family can stress plants, thereby triggering the production of free radicals (Bashir et al., 2007; Parween et al., 2012). Free radicals are highly reactive molecules that can damage cell membranes. Carotenoid content increased when plants were exposed to pyrethroid and organophosphate as a response to increased free radicals (Prasad et al., 2015). Pyrethroid and organophosphate also produce reactive oxygen species and cause lipid/ membrane peroxidation (Prasad et al., 2015). Superoxide dismutase, an antioxidant enzyme in plants, increased when plants were exposed to these pesticides (Parween et al., 2012; Prasad et al., 2015). Deltamethrin, a pyrethroid, inhibits the formation of spindle fibers during cell division, thus producing abnormal cells (Chauhan et al., 1986). Pyrethroids may also reduce photosynthetic light use (Rózsavölgyi and Horváth, 2008). Insecticides from organophosphate and carbamate families can inhibit nitrification because nitrifying bacteria are sensitive to these insecticides (Lin et al., 1972). Imidacloprid can reduce seed germination (Dubey and Fulekar, 2011; Stevens et al., 2008), and deltamethrin can extend the vegetative cycle of plants (Fidalgo et al., 1993). Pyriproxyfen, 
Table 1. Pesticides detected in irrigation runoff and retention ponds from container nursery production sites.

\begin{tabular}{|c|c|c|c|}
\hline Pesticide detected & Concn $^{\mathrm{z}}$ & Water sampled & Citation \\
\hline Simazine & $2.2 \pm 0.7 \mathrm{ppm}$ & Irrigation runoff & \\
\hline Isoxaben & $0.75 \mathrm{ppm}$ & Irrigation runoff & \\
\hline Trifluralin & $5.00 \mathrm{ppb}$ & Containment pond & \\
\hline Isoxaben & $55.0 \mathrm{ppb}$ & Containment pond & \\
\hline Oxyfluorfen & $<1.00 \mathrm{ppb}$ & Containment pond & \\
\hline Oryzalin & $<1.00 \mathrm{ppb}$ & Containment pond & \\
\hline Bifenthrin & $10.6 \mathrm{ppb}$ & Runoff near production area & Kabashima et al., 2004 \\
\hline Cis-permethrin & $24.6 \mathrm{ppb}$ & Runoff near production area & \\
\hline Trans-permethrin & $4.4 \mathrm{ppb}$ & Runoff near production area & \\
\hline Metalaxyl & $2.19 \mathrm{ppm}$ & Irrigation runoff & \\
\hline Oxyfluorfen & $<0.10 \mathrm{ppm}$ & Containment pond & Riley et al., 1994 \\
\hline Pendimethalin & $4 \mathrm{ppb}$ & Containment pond & \\
\hline Oxyfluorfen & $<0.01 \mathrm{ppm}$ & Retention pond & Camper et al., 1994 \\
\hline Pendimethalin & $4 \mathrm{ppb}$ & Retention pond & \\
\hline Oryzalin & $0.16 \mathrm{ppm}$ & Retention pond & \\
\hline Chlorpyrifos & $1.59 \mathrm{ppb}$ & Water entering retention pond & Mangiafico et al., 2008 \\
\hline Diazinon & $17.4 \mathrm{ppb}$ & Water entering retention pond & \\
\hline Bifenthrin & $20.6 \mathrm{ppb}$ & Water entering retention pond & \\
\hline Cypermetherin & $2.00 \mathrm{ppt}$ & Water entering retention pond & \\
\hline Thiophanate-methyl & $1.64 \mathrm{ppm}$ & Irrigation runoff & Briggs et al., 2002b \\
\hline
\end{tabular}

Reported concentrations are for the maximum amount detected and always occurred during first flush of runoff.

${ }^{\mathrm{z}} \pm$ Deviation either positive or negative from the mean value. $1 \mathrm{ppm}=1 \mathrm{mg} \cdot \mathrm{L}^{-1} ; 1 \mathrm{ppb}=1 \mu \mathrm{g} \cdot \mathrm{L}^{-1} ; 1 \mathrm{ppt}=1 \mathrm{pg} \cdot \mathrm{L}^{-1}$

fipronil, imidacloprid, and thiamethoxam reduce the phosphorus solubilization activity of rhizosphere bacteria, causing a reduction in phosphorus available for plant uptake (Ahemad and Khan, 2011). Indole acetic acid (IAA) production from rhizosphere bacteria is also reduced by these pesticides, which may lead to reductions in cell elongation and growth (Ahemad and Khan, 2012). Oxydemeton-methyl and pirimicarb, when combined with fungicides mancozeb and flusilazol, reduced photosynthesis by inhibiting phosphorylation and adenosine triphosphate (ATP) formation (Untiedt and Blanke, 2004). Hence, the presence of insecticides in retention ponds has the potential to induce phytotoxicity.

FungicIDEs. Nursery managers often apply various fungicides to protect crops from a wide range of fungal diseases. Although fungicides may be effective at controlling fungal diseases, they may also be phytotoxic to sensitive plants. (Chase, 2010; Getter, 2015). Fungicides may contain inorganic ingredients, such as copper and sulfur, or organic compounds, like metalaxyl or triflumizole. Both inorganic and organic compounds can induce phytotoxic effects on plants (Petit et al., 2012; Tjosvold et al., 2005). Fungicides may affect plant growth and performance by direct inhibition of photosynthesis or by degradation of ribulose 1,5 bisphosphate (RuBP) carboxylase (Van Assche and Clijsters, 1990). They also may slow regeneration of RuBP, reduce gs, lessen the stomatal opening, and degrade photosystems (Nason et al., 2007; Xia et al., 2006). Fungicides can also oxidize and destroy membranes. Destroying membranes leads to the reduction of electron transport reactions, altered source sink relations, and reductions in pigments such as chlorophyll a, chlorophyll b, and carotenoids (Benton and Cobb, 1997; Saladin et al., 2003; Vinit-Dunand et al., 2002). Fungicides have also been reported to reduce photochemical efficiency through the reduction in photochemical quenching (Dias, 2012). There have been a few instances of increased photosynthesis and growth in response to relatively low doses of fungicide treatment (Saladin et al., 2003; Untiedt and Blanke, 2004).

\section{Properties of pesticides that may affect phytotoxicity of runoff}

Pesticides differ in their physical and chemical properties. Ultimately, these properties determine the potential for compounds to move with 
WORKSHOP

Table 2. Common herbicides applied at nurseries and their effects on plants.

\begin{tabular}{|c|c|c|c|c|}
\hline Site of action & $\begin{array}{l}\text { WSSA } \\
\text { group }^{z}\end{array}$ & Effect on plants & Common name & Citation \\
\hline $\begin{array}{l}\text { 5-enolpyruvyl-shikimate-3- } \\
\text { phosphate (ESPS) synthase } \\
\text { inhibitors }\end{array}$ & 9 & $\begin{array}{l}\text { These herbicides are absorbed } \\
\text { through foliage and translocated } \\
\text { through phloem. They inhibit } \\
\text { the synthesis of } 5 \text { - } \\
\text { enolpyruvylshikimate-3- } \\
\text { phosphate (EPSP). EPSP is a key } \\
\text { enzyme in the shikimic acid } \\
\text { pathway that produces the } \\
\text { amino acids tryptophan, } \\
\text { tyrosine, and phenylalanine. } \\
\text { Inhibition of this enzyme ceases } \\
\text { essential amino acid formation, } \\
\text { causing plant death }\end{array}$ & Glyphosate & Shaner, 2006 \\
\hline
\end{tabular}

(Continued on next page) 
Table 2. (Continued) Common herbicides applied at nurseries and their effects on plants.

\begin{tabular}{|c|c|c|c|c|}
\hline Site of action & $\begin{array}{l}\text { WSSA } \\
\text { group }^{z}\end{array}$ & Effect on plants & Common name & Citation \\
\hline $\begin{array}{l}\text { Protoporphyrinogen oxidase } \\
\quad(\text { PPO) inhibitors }\end{array}$ & 14 & $\begin{array}{l}\text { Protoporphyrinogen oxidase } \\
\text { (PPO) enzyme oxidizes } \\
\text { protoporphyrinogen IX to } \\
\text { protoporphyrin IX. } \\
\text { Protoporphyrin IX is the } \\
\text { precursor to chlorophyll and } \\
\text { heme synthesis. PPO inhibitor } \\
\text { blocks synthesis of the PPO } \\
\text { enzyme, leading to reductions in } \\
\text { chlorophyll formation. This } \\
\text { ultimately reduces } \\
\text { photosynthesis. Increased } \\
\text { accumulation of } \\
\text { protoporphyrinogen IX, in the } \\
\text { presence of light, reacts with } \\
\text { molecular oxygen to produce } \\
\text { reactive oxygen species (ROS). } \\
\text { ROS are very unstable and } \\
\text { destroy cell membranes, causing } \\
\text { cell leakage. }\end{array}$ & Oxyfluorfen & Lee and Duke, 1994 \\
\hline $\begin{array}{l}\text { Long-chain fatty acid (LCFA) } \\
\text { inhibitors }\end{array}$ & 15 & $\begin{array}{l}\text { This class of herbicide inhibits the } \\
\text { formation of long-chain fatty } \\
\text { acids (LCFA) by reducing the } \\
\text { incorporation of stearic acid, } \\
\text { malonic, and acetate in the } \\
\text { chain. It also inhibits the } \\
\text { formation of enzymes required } \\
\text { for the elongation of LCFA. } \\
\text { LCFA inhibitors also inhibit } \\
\text { LCFA incorporation in the cell } \\
\text { wall. LCFA is an essential } \\
\text { component of the plasma } \\
\text { membrane. Inhibiting its } \\
\text { formation will kill the cell and } \\
\text { plants. }\end{array}$ & $\begin{array}{l}\text { Acetochlor, } \\
\text { metolachlor }\end{array}$ & $\begin{array}{l}\text { Matthes et al., 1998; } \\
\text { Schmalfuß et al., } 1998\end{array}$ \\
\hline Microtubule assembly inhibitors & 3 & $\begin{array}{l}\text { This class of herbicide binds with } \\
\text { free tubulin. Tubulin } \\
\text { synthesizes microtubules, and } \\
\text { this is essential for cell division. } \\
\text { When herbicides bind to } \\
\text { tubulin, tubulin cannot } \\
\text { synthesize microtubules; hence, } \\
\text { the cell is arrested in the dividing } \\
\text { stage. Symptoms of injury } \\
\text { include swollen root tips. }\end{array}$ & $\begin{array}{l}\text { Pendimethalin, } \\
\text { trifluralin, oryzalin }\end{array}$ & Sandmann et al., 1980 \\
\hline
\end{tabular}

Adapted from Al-Khatib, 2019; Case et al., 2005; Prather et al., 2000; Reade and Cobb, 2002; Ross and Childs, 1996; University of Wisconsin, 2013.

${ }^{z}$ Weed Science Society of America.

runoff water and cause phytotoxicity. Some of the basic properties of pesticides and how those properties determine the fate and potential phytotoxicity of various pesticide compounds are considered below (adapted from National Pesticide Information Center, 2019).

Solubility. Solubility is the ability of a pesticide compound to dissolve in a solvent (water). It is measured in milligrams of a compound per liter of solvent or parts per million. Pesticides with solubility less than $10 \mathrm{mg} \cdot \mathrm{L}^{-1}$ are considered to have low water solubility, whereas pesticides with solubility higher than $1000 \mathrm{mg} \cdot \mathrm{L}^{-1}$ are highly water-soluble. Highly soluble pesticides are likely to dissolve and move with runoff water to containment ponds where their concentration may build. Pesticides like acephate $\left(818,000 \mathrm{mg} \cdot \mathrm{L}^{-1}\right)$, glyphosate $\left(1,050,000 \mathrm{mg} \cdot \mathrm{L}^{-1}\right)$, and mefenoxam $\left(8400 \mathrm{mg} \cdot \mathrm{L}^{-1}\right)$ are highly water-soluble and may accumulate in retention ponds.

Adsorption. Adsorption or sorption coefficient $\left(\mathrm{K}_{\mathrm{d}}\right)$ is a measure of how well compounds bind to soil particles. However, $K_{d}$ does not take 
into consideration soil organic matter, which is the main sorbent of pesticides in container substrates. Therefore, the organic carbon-water coefficient $\left(\mathrm{K}_{\mathrm{oc}}\right)$ is used to estimate pesticide adsorption of container media (Wauchope et al., 2002). Pesticides with a higher adsorption coefficient adsorb to substrate particles and ground surface. Hence, they are less likely to move with runoff water compared with compounds with low $\mathrm{K}_{\mathrm{oc}}$. Within retention ponds, pesticides with high $\mathrm{K}_{\mathrm{oc}}$ may also bind to sediment and are less likely to move with recycled irrigation. Bifenthrin $\left(\mathrm{K}_{\mathrm{oc}}=131,000-302,000\right)$, chlorpyrifos $\left(\mathrm{K}_{\mathrm{oc}}=7000-25,000\right)$, and oxyfluorfen $\left(\mathrm{K}_{\mathrm{oc}}=8900\right)$ have high adsorption coefficients and are less likely to move with runoff water. Regardless, some pesticides such as oxyfluorfen can cause crop damage, even at a very low concentration $(0.01$ $\mathrm{mg} \cdot \mathrm{L}^{-1}$ ) (Poudyal et al., 2018).

Persistence. Pesticide degradation occurs via various factors such as light, water, chemicals, microbes, or plants. The half-life $\left(\mathrm{DT}_{50}\right)$ refers to the time required for a pesticide to reduce to half of the concentration initially applied. The half-life of pesticides varies depending on environmental conditions. Based on the half-life, pesticides are classified as nonpersistent $\left(\mathrm{DT}_{50}<30 \mathrm{~d}\right)$, moderately persistent $\left(\mathrm{DT}_{50}=3 \mathrm{l}-90 \mathrm{~d}\right)$, and persistent $\left(\mathrm{DT}_{50}>90 \mathrm{~d}\right)$ (Deer, 2004). Persistent pesticides have greater potential to remain longer in retention ponds. With other factors remaining constant, a pesticide with a longer half-life (persistent) has higher potential to cause phytotoxic effect on plants; however, pesticides with short half-lives (nonpersistent) can require frequent reapplication that can increase their concentration in retention ponds. Pesticides such as isoxaben (2-6.6 months), oryzalin (1.4-4.4 months), and oxyfluorfen (1-6 months) may have long halflives; therefore, they can still be present even after months in retention ponds.

Volatility. Volatility is a measure of the potential of a compound to evaporate; it is usually measured in millimeters of mercury $(\mathrm{Hg})$. Pesticides with vapor pressure $<0.000001 \mathrm{~mm} \mathrm{Hg}$ are less volatile, whereas pesticides with vapor pressure $>0.01 \mathrm{~mm} \mathrm{Hg}$ are highly volatile.
During pesticide applications, vapor from volatile pesticides may quickly drift to nearby nontarget plants and may cause immediate phytotoxicity in sensitive species. Highly volatile pesticides are less likely to appear in runoff and to be transported to a containment pond. Pesticides like chlorpyrifos $(0.00002 \mathrm{~mm} \mathrm{Hg})$ and triflumizole $(0.0000014 \mathrm{~mm} \mathrm{Hg})$ are volatile and may drift to nearby areas, causing injury to sensitive species. The volatility of pesticides, although important, is not constant and differs with environmental conditions and interactions with other chemicals. For example, volatilization may reduce the half-life of chlorpyrifos in surface water to as short as 0.3 to $3.2 \mathrm{~d}$. However, in a retention pond, this may extend to 1 to 2 months due to slower microbial transformation and lower $\mathrm{pH}$ of collected water (Leistra et al., 2006; Lu et al., 2006a; Meikle et al., 1983).

\section{Factors affecting the potential for crop injury}

Pesticide concentrations are low in nursery runoff water, and they are even lower in retention ponds compared with labeled application rates. The recommended rate of isoxaben application is $\approx 4500 \mathrm{mg} \cdot \mathrm{L}^{-1}$ (calculated using label rate), and the concentration found in retention pond is $\approx 0.055 \mathrm{mg} \cdot \mathrm{L}^{-1}$ (Wilson et al., 1996). A similar pattern is true for most pesticides, but irrigating with runoff can result in chronic plant exposure to pesticides. Long-term exposure to low concentrations of residual pesticides has the potential to cause crop injury. This potential for damage depends on a series of factors, including plant sensitivity, pesticide type, pesticide dose, length of pesticide exposure, and growth stage when plants are exposed.

Pesticides. Certain pesticides may be more likely to cause plant injury than others. Baz and Fernandez (2002) observed that isoxaben (4 ppm) was more damaging to semi-aquatic woody nursery plants than oryzalin $(4 \mathrm{ppm})$ in terms of growth and photosynthetic responses. Similarly, isoxaben $(5 \mathrm{ppm})$ had a greater impact on growth and photosynthetic parameters of semiaquatic herbaceous perennials compared with oryzalin $(5 \mathrm{ppm})$ (Fernandez et al., 1999). In a large phytotoxicity trial by
Mathers et al. (2012), phytotoxic damage was observed on rose (Rosa sp.) when sprayed with isoxaben $(2.25 \mathrm{lb} /$ acre) plus oryzalin (0.8 qt/acre), but exposure to indaziflam $(38.1 \mathrm{lb} /$ acre $)$ did not cause damage. In the same study, the combined application of flumioxazin $(0.612 \mathrm{fl} \mathrm{oz} /$ acre $)$ and oryzalin $(25.85 \mathrm{fl} \mathrm{oz} /$ acre $)$ injured compact euonymus (Euonymus alatus) and common purple lilac (Syringa sp.), but dimethenamid-P (13.4 fl oz/acre) plus pendimethalin $(0.04 \mathrm{qt} / \mathrm{acre})$ did not induce phytotoxicity on compact euonymus (Mathers et al., 2012). In a fungicide study, ghent azalea (Rhododendron daviesi) exhibited phytotoxicity resembling sunburn and leaf lesions after 1 week of treatment with a sulfur-based fungicide (19 ppm); however, other fungicides, such as propiconazole $\left(0.088 \mathrm{~mL} \cdot \mathrm{L}^{-1}\right)$ and trifloxystrobin $\left(0.15 \mathrm{~mL} \cdot \mathrm{L}^{-1}\right)$, did not produce phytotoxicity (Vea and Palmer, 2017a). In the same study, copper sulfate pentahydrate $\left(0.655 \mathrm{~mL} \cdot \mathrm{L}^{-1}\right)$ produced phytotoxic damage on flowering dogwood (Cornus florida) but chlorothalonil (0.36 $\mathrm{mL} \cdot \mathrm{L}^{-1}$ ) was completely safe (Vea and Palmer, 2017a). In a dose-response study including isoxaben (0-1.4 ppm), oxyfluorfen (0-0.02 ppm), and chlorpyrifos (0-0.4 ppm), panicle hydrangea (Hydrangea paniculata), silky dogwood (Cornus obliqua), and hosta (Hosta sp. 'Gold Standard') were exposed to low doses of each pesticide. Of the three pesticides, only oxyfluorfen (0.005-0.02 ppm) caused phytotoxic damage (Poudyal et al., 2018). Neem oil extract $\left(7 \mathrm{~mL} \cdot \mathrm{L}^{-1}\right)$ reduced photosynthesis and growth of gerbera daisy (Gerbera sp.), but the insecticide abamectin (1.51 ppm) had no effect (Spiers et al., 2008). Insecticides such as cinnamaldehyde $\left(1.494 \mathrm{~mL} \cdot \mathrm{L}^{-1}\right)$ and pyrethrin $\left(1.164 \mathrm{~mL} \cdot \mathrm{L}^{-1}\right)$ were phytotoxic on spanish lavender (Lavandula stoechas), oregano (Origanum vulgare), rosemary (Rosmarinus officinalis), St. John's wort (Hypericum perforatum), woolly thyme (Thymus psendolanuginosus), and nutmeg thyme (Thymus praecox); however, insecticides such as capsaicin $\left(62.25 \mathrm{~mL} \cdot \mathrm{L}^{-1}\right)$ and azadirachtin $(3.75 \mathrm{ppm})$ were safe on those species (Cloyd and Cycholl, 2002).

Plant Sensitivity. Plants often differ in their sensitivity to pesticides. In an evaluation trial of isoxaben $(0.045 \mathrm{lb} / \mathrm{acre})$ and pendimethalin (2 lb/acre), both compounds reduced the plant height of winter 
creeper (Euonymus fortune 'Emerald n Gold') but did not affect heller's japanese holly (Ilex crenata 'Helleri') (Regan and Ticknor, 1987). In a study by Bhandary et al. (1997a), oryzalin, oxyfluorfen, and isoxaben were applied separately with irrigation water at either 1 or $10 \mathrm{ppm}$. Isoxaben reduced fresh root mass for heller's japanese holly at 10 ppm, but it did not affect dwarf gardenia ( Gardenia jasminoides radicans). Oryzalin (10 ppm) and oxyfluorfen (10 ppm) reduced shoot fresh weight of fountain grass (Pennisetum rupeli), but it did not affect shoot fresh weight of daylily (Hemerocallis bybrid), dwarf gardenia or heller's japanese holly. In a similar study, when dwarf gardenia and fountain grass were irrigated with $0.01,0.1$, and 1 ppm of oryzalin, 1 ppm reduced root and shoot weight for fountain grass but did not affect dwarf gardenia (Bhandary et al., 1997b). Isoxaben, even at the label-recommended rate, caused serious phytotoxic damage to foxglove (Digitalis purpurea), purple coneflower (Echinacea purpurea), lamb's ears (Stachys byzantine), and false spirea (Astilbe sp.), but it was safe on statice (Limonium latifolium), little bluestem (Schizachyrium scoparium), and red maple (Acer rubrum) (Vea and Palmer, 2017b). Application of oxyfluorfen plus oryzalin (12 lb/acre) on woolly yarrow (Achillea tomentosa) caused stunted growth $(70 \%$ to $80 \%$ growth reduction), but woolly thyme was unaffected (Staats et al., 1998).

Pesticide dose ANd exposure. Although pesticide concentrations in retention ponds are low compared with application rates, continuous irrigation even with low doses may build and cause phytotoxic responses. Miticides such as phosmet (applied at 0.6 and $1.2 \mathrm{~g} \cdot \mathrm{L}^{-1}$ ) and vinyl dimethyl phosphate (applied at $0.6,1.2$, and $2.4 \mathrm{~g} \cdot \mathrm{L}^{-1}$ ) had dosedependent effects on flowers of various cultivars of chrysanthemum (Chrysanthemum sp.), but damage was only seen with higher doses (Poe, 1970). In a study by Bhandary et al., (1997a), 1 ppm of oryzalin reduced fresh shoot weight of fountain grass by $13.5 \%$ whereas $10 \mathrm{ppm}$ reduced growth by $92.7 \%$. Similarly, 1 ppm of oxyfluorfen reduced the fresh shoot weight of fountain grass by $11.4 \%$ compared with $31.2 \%$ by $10 \mathrm{ppm}$ of oxyfluorfen. In the same study, isoxaben at 1 and $10 \mathrm{ppm}$ increased root phytotoxicity (based on a rating of 0 to 10 ) by $37 \%$ and $56 \%$, respectively. Indaziflam (herbicide) was applied at 200,400 , and $800 \mathrm{lb} /$ acre to different ornamental plants and the application was repeated after 4 weeks. For smooth hydrangea (Hydrangea arborescens 'Invincibelle'), big leaf hydrangea (Hydrangea macrophylla 'Endless summer'), and judd viburnum ( $V i$ burnum $X$ Juddii), increasing the dose of pesticides increased phytotoxic damage, and repeated applications further exacerbated the damage (Mathers et al., 2012). Isoxaben application at the recommended rate (0.5-1 lb/acre) had no phytotoxic effect on butterfly bush (Buddleia davidii) or hairawn muhly (Mublenbergia capillaris), but isoxaben application produced phytotoxic symptoms when the dose was increased to $2 \mathrm{lb} / \mathrm{acre}$ (Vea and Palmer, 2017b).

GROWTH STAGES AND PLANT PARTS. The sensitivity of nursery crops to pesticides is likely to vary depending on the growth stage of the plants at the time of application. However, research detailing the phytotoxic response of plants to pesticide application at various growth stages is limited, and results have been variable. Generally, pesticide labels suggest avoiding pesticide application at the seedling stage or younger. In a study by Richardson (1972), phytotoxicity in sugarcane (Saccharum sp.) was higher when $2,4-\mathrm{D}\left(3.3 \mathrm{~kg} \cdot \mathrm{ha}^{-1}\right)$ was applied at later stages of growth. However, for sunflower (Helianthus annums), the application of an herbicide (flumioxazin, $30 \mathrm{~g} \cdot \mathrm{ha}^{-1}$ ) at early stages of growth caused greater photosynthesis reduction and slower recovery from damage compared with application at later stages (Jursik et al., 2013). Chlordimeform $\left(1.2 \mathrm{~g} \cdot \mathrm{L}^{-1}\right)$, an insecticide, caused phytotoxic damage to younger leaves of chrysanthemum but had no effect on older leaves. Cyhexatin (0.14 $\left.\mathrm{g} \cdot \mathrm{L}^{-1}\right)$, a miticide, caused phytotoxic damage to flowers of chrysanthemum, but the foliage was unaffected (Poe, 1970).

\section{Mitigating risks from residual pesticides in recycled runoff}

As indicated, residual pesticides in recycled runoff can potentially damage nursery crops under certain conditions. Fortunately, there are several ways to reduce the risk of phytotoxicity arising from irrigation with recycled runoff. A complete discussion of mitigation technologies is beyond the scope of this review. We present a few examples of techniques to reduce or remediate pesticides in runoff. For a more complete review of mitigation technologies, readers are referred to the work by Majsztrik et al., (2017) and to the Clean WateR $^{3}$ website (Clean WateR ${ }^{3}$, 2019).

PEST I C I D E - D E P E N D E N T REDUCTION. The potential for a pesticide to be present in runoff depends on the formulation of the pesticide. In a study of the effect of formulation on runoff of isoxaben and trifluralin, the concentration of isoxaben in runoff was $25 \%$ to $61 \%$ greater when the product was applied as a granular formulation compared with a spray application (Briggs et al., 2002a). For trifluralin, the formulation did not affect the runoff concentration (Briggs et al., 2002a). The type of nursery bed liner can also affect pesticide runoff. When comparing nursery bed flooring, plastic groundcover had the greatest isoxaben runoff, followed by landscape fabric and gravel. Runoff losses from both granular and sprayable formulations were higher for plastic and fabric compared with gravel (Wilson et al., 1995). The irrigation design is also effective for controlling pesticide runoff. Cyclic irrigation, whereby total water for each day is applied in short intermittent cycles, usually has less pesticide runoff compared with continuous irrigation (Briggs et al., 1998b). Using pesticides with low solubility, whenever possible, can also reduce the concentration of pesticides in runoff (Riley, 2003). Plant shape and size and container size and spacing can also influence pesticide runoff. Minimizing plant spacing when applying pesticides can reduce nontarget applications. Herbicide application losses were $23 \%, 51 \%$, and $80 \%$ when spacing was 0,8 , and 12 inches between containers, respectively (Gilliam et al., 1992). Highly soluble and less 
volatile pesticides such as isoxaben and thiophanate-methyl have greater runoff potential compared with less soluble pesticides such as chlorpyrifos and trifluralin (Briggs et al., 1998a).

Constructed WeTlands AND VEGETATIVE BUFFER. A constructed wetland is a marsh designed to hold and treat runoff, whereas vegetative buffers are usually narrow strips of land established with plants in the path of runoff. Both of these systems reduce pesticide concentration through adsorption, microbial degradation, volatilization, infiltration, and plant uptake (Newman, 2010). In a review of pesticide removal using constructed wetlands, pesticides such as organochlorine (97\% removal) and organophosphate $(94 \%$ removal $)$ were almost completely removed, but pyrethroid removal was $\approx 80 \%$ (Vymazal and Březinová, 2015). Pesticide removal efficiency of constructed wetlands and vegetative buffer increases with the pesticide $\mathrm{K}_{\mathrm{oc}}$ value and runoff retention time (Stearman et al., 2003; Vymazal and Březinová, 2015). Both vegetative buffers and constructed wetland systems can reduce pesticide concentrations in runoff from $50 \%$ to $99 \%$ (Otto et al., 2016), and they are particularly effective at removing pyrethroids (Bennett et al., 2005; Budd et al., 2009). Runoff retention time for pesticide removal may vary from a few hours to days depending on the properties of pesticides (Vymazal and Březinová, 2015).

SAND FILTERs. Well-engineered sand filter systems have great potential to remove runoff pesticides (Hedegaard and Albrechtsen, 2015). A rapid sand filter can remove pesticides like mecoprop (MCPP), bentazone, and glyphosate, with a success rates varying from $7 \%$ to $85 \%$ (Hedegaard and Albrechtsen, 2014). Removal of pesticides such as trifluralin, fenitrothion, and endosulfan have also been achieved using sand filters (Aslan, 2005). The microbial community on the top layer of slow sand filter can degrade pesticides, thus creating an effective pesticide removal system (Escolà Casas and Bester, 2015; Samuelsen et al., 2017).

ACTIVATED CARBON FILTERS AND FILTER socks. Activated carbon is a positively charged substrate that can adsorb polar or negatively charged pesticides. The efficacy of carbon filters depends on the type of carbon filter material used, temperature, and flow rate of the filtration system. Activated carbon filters effectively remove agricultural pesticides (Hetrick et al., 2011; Jusoh et al., 2011; Kabashima et al., 2004; Martìn-Gullón and Font, 2001) as runoff water passes through the carbon filter. Removal efficiency may be as high as $99.5 \%$ for organic compounds and negatively charged ions (Majsztrik et al., 2017). Carbon filters with granular activated carbon completely removed acephate and paclobutrazol when the contact time was $64 \mathrm{~s}$. The same system also removed bifenthrin, chlorpyrifos, imidacloprid, and glyphosate by $72.2 \%$, $89 \%, 85.3 \%$, and $99 \%$, respectively (Grant et al., 2019).

Filter socks are long tubes made of mesh material that are commonly used to intercept sediment carried in runoff. In a low-flow system, fill material such as wood chips can be used to remove pesticides from runoff water; however, in a high-flow system, filter socks may not be very effective (Majsztrik et al., 2017; Roseth and Haarstad, 2010). Different substrates like pine bark, sphagnum moss, peat, sand, and compost are effective filler material for pesticide removal. In a study testing the efficacy of substrate for the removal of 21 different pesticides, pine bark was the most efficient and removed nearly 100\% for 20 different pesticides. Peat removed nearly $100 \%$ of 16 different pesticides (Roseth and Haarstad, 2010). Substrates with a high adsorption coefficient such as pine bark will have higher removal efficiency (Roseth and Haarstad, 2010). In a study by Shipitalo et al. (2010), filter socks filled with compost were effective for removing sediments and agrochemicals such as alachlor $(18 \%$ removal) and glyphosate $(5 \%$ removal) from surface runoff. In addition to these strategies, other best management practices can help manage pesticides in nursery runoff (Southern Nursery Association, 2013).

\section{Conclusions}

Managing water resources is a major concern for nursery growers throughout the United States. Growers in many regions face the prospect of increasing scrutiny and regulation by environmental agencies. Therefore, nursery growers are looking for alternative ways to meet the crop water demand. Capturing and reusing runoff water may be an option to cope with water shortages and environmental regulations, but the risk associated with pesticide phytotoxicity may hinder grower adoption of recycling and reuse technologies. Pesticides can cause phytotoxic responses by interfering with metabolic processes of plants, including inhibiting tubulin formation, inhibiting chlorophyll formation, and penetrating lipid membranes. This interference leads to reductions in plant photosynthesis and growth. However, pesticide concentrations in remediation ponds are typically several orders of magnitude lower than the application rate due to dilution from irrigation and rainwater (Camper et al., 1994), thereby greatly reducing potential phytotoxicity in nursery crops. Nursery growers need to be cautious when irrigating with captured runoff that may contain herbicides and certain insecticides. Herbicides such as oxyfluorfen may be phytotoxic at very low concentration. Plants, such as rose, may be sensitive to numerous pesticides. Even with low pesticide concentrations, repeated applications may build pesticides and cause phytotoxic symptoms.

Among pesticides, herbicides typically pose the greatest risk because of the similarity between pest that is controlled (weeds) and the crop plant. Nonetheless, insecticides and fungicides may also affect nursery crops; fungicides containing copper sulfate may cause phytotoxic responses. Other factors to consider include the pesticide solubility, adsorption potential, and half-life of pesticides. Pesticides with high solubility, low adsorption to organic matter, and a long half-life are more problematic because they have a higher tendency to be carried in runoff and to degrade very slowly. The growth stage of plants is also important when considering potential phytotoxicity. Exposure to pesticides at early stages of growth may have greater potential for injury, but research of the growth stage and phytotoxicity of nursery crops is very limited. 
The best strategy for preventing pesticide phytotoxicity is minimizing pesticide movement to retention ponds. Reducing container spacing during pesticide application can reduce off-target pesticide loss. Using less soluble pesticides will lower the potential for pesticides to be in recycled irrigation water. Creating vegetative buffer zones and using filter socks to trap pesticides will reduce pesticide movement and accelerate their degradation. All of these techniques lower the concentrations of pesticides in retention ponds. Therefore, capture and reuse of runoff for irrigation may be viable and sustainable for nursery growers and may help them deal with water scarcity and environmental issues.

\section{Literature cited}

Ahemad, M. and M.S. Khan. 2011. Effects of insecticides on plant-growth-promoting activities of phosphate solubilizing rhizobacterium Klebsiella sp. strain PS19. Pestic. Biochem. Physiol. 100:51-56.

Ahemad, M. and M.S. Khan. 2012. Effects of pesticides on plant growth promoting traits of Mesorbizobium strain MRC4. J. Saudi Soc. Agr. Sci. 11:63-71.

Al-Khatib, K. 2019. Herbicide symptoms. 13 Mar. 2019. <http://herbicidesymptoms. ipm.ucanr.edu/>.

Andersen, L. and C.W. Hansen. 2000. Leaching of nitrogen from container plants grown under controlled fertigation regimes. J. Environ. Hort. 18:8-12.

Aslan, Ş. 2005. Combined removal of pesticides and nitrates in drinking waters using biodenitrification and sand filter system. Process Biochem. 40:417-424.

Atland, J. 2014. Weed control in herbaceous perennial container production. 5 May 2019. <https://gpnmag.com/article/weedcontrol-herbaceous-perennial-containerproduction $/>$.

Bailey, D., T. Bilderback, and D. Bir. 1999. Water considerations for container production of plants. North Carolina Coop. Ext. Serv. 557. 8 May 2019. <https://content.ces.ncsu.edu/waterconsiderations-for-container-productionof-plants $>$.

Bashir, F., Mahmooduzzafar, T.O. Siddiqi, and M. Iqbal. 2007. The antioxidative response system in Glycine $\max (\mathrm{L}$.) Merr. exposed to deltamethrin, a synthetic pyrethroid insecticide. Environ. Pollut. 147:94100 .
Baz, M. and R.T. Fernandez. 2002. Evaluating woody ornamentals for use in herbicide phytoremediation. J. Amer. Soc. Hort. Sci. 127:991-997.

Beeson, R.C., M.A. Arnold, T.E. Bilderback, B. Bolusky, S. Chandler, H.M. Gramling, J.D. Lea-Cox, J.R. Harris, P.J. Klinger, H.M. Mathers, J.M. Ruter, and T.H. Yeager. 2004. Strategic vision of container nursery irrigation in the next ten years. J. Environ. Hort. 22:113-115.

Beeson, R.C. and G.W. Knox. 1991. Analysis of efficiency of overhead irrigation in container production. HortScience 26:848-850.

Bennett, E.R., M.T. Moore, C.M. Cooper, S. Smith, F.D. Shields, K.G. Drouillard, and R. Schulz. 2005. Vegetated agricultural drainage ditches for the mitigation of pyrethroid-associated runoff. Environ. Toxicol. Chem. 24:2121-2127.

Benton, J.M. and A.H. Cobb. 1997. The modification of phytosterol profiles and in vitro photosynthetic electron transport of Galium aparine L. (cleavers) treated with the fungicide, epoxiconazole. Plant Growth Regulat. 22:93-100.

Bhandary, R.M., T. Whitwell, and J. Briggs. 1997a. Growth of containerized landscape plants is influenced by herbicides residues in irrigation water. Weed Technol. 11:793-797.

Bhandary, R., T. Whitwell, J.A. Briggs, and R.T. Fernandez. 1997b. Influence of surflan (oryzalin) concentrations in irrigation water on growth and physiological processes of Gardenia jasminoides radicans and Pennisetum rupelli. J. Environ. Hort. 15:169-172.

Briggs, J.A., M.B. Riley, and T. Whitwell. 1998a. Quantification and remediation of pesticides in runoff water from containerized plant production. J. Environ. Qual. 27:814-820.

Briggs, J.A., T. Whitwell, R.T. Fernandez, and M.B. Riley. 2002a. Formulation effects on isoxaben and trifluralin in runoff water from container plant nurseries. Weed Sci. 50:536-541.

Briggs, J.A., T. Whitwell, R.T. Fernandez, and M.B. Riley. 2002b. Effect of integrated pest management strategies on chlorothalonil, metalaxyl, and thiophanate-methyl runoff at a container nursery. J. Amer. Soc. Hort. Sci. 127:1018-1024.

Briggs, J.A., T. Whitwell, and M.B. Riley. 2003. Effect of delayed irrigation on isoxaben and oryzalin runoff from a container nursery. Weed Sci. 51:463-470.

Briggs, J., T. Whitwell, M.B. Riley, and T. Lee. 1998b. Cyclic irrigation and grass waterways combine to reduce isoxaben losses from container plant nurseries. J. Environ. Hort. 16:235-238.

Broschat, T.K. 1995. Nitrate, phosphate, and potassium leaching from containergrown plants fertilized by several methods. HortScience 30:74-77.

Budd, R., A. O'Geen, K.S. Goh, S. Bondarenko, and J. Gan. 2009. Efficacy of constructed wetlands in pesticide removal from tailwaters in the Central Valley, California. Environ. Sci. Technol. 43:2925-2930.

Bush, E.A., C. Hong, and E.L. Stromberg. 2003. Fluctuations of Phytophthora and Pythium spp. in components of a recycling irrigation system. Plant Dis. 87:15001506.

Camper, N.D., T. Whitwell, R.J. Keese, and M.B. Riley. 1994. Herbicide levels in nursery containment pond water and sediments. J. Environ. Hort. 12:8-12.

Case, L.T., H.M. Mathers, and A.F. Senesac. 2005. A review of weed control practices in container nurseries. HortTechnology 15:535-545.

Chase, A. 2010. Testing for phytotoxicity. 8 May 2019 . <https://www. greenhousegrower.com/production/plantculture/testing-for-phytotoxicity/ $>$.

Chauhan, L.K.S., T.S. Dikshith, and V. Sundararaman. 1986. Effect of deltamethrin on plant cells I. Cytological effects on the root meristems of Allium сера. Mutat. Res. 171:25-30.

Clean WateR ${ }^{3}$. 2019. Clean wate ${ }^{3}$ reduce, remediate and recycle. 8 May 2019. $<$ https://www.cleanwater3.org/default. asp>.

Cloyd, R.A. and N.L. Cycholl. 2002. Phytotoxicity of selected insecticides on greenhouse-grown herbs. HortScience 37:671-672.

Colangelo, D.J. and M.H. Brand. 2001. Nitrate leaching beneath a containerized nursery crop receiving trickle or overhead irrigation. J. Environ. Qual. 30:15641574.

Conley, D.J., H.W. Paerl, R.W. Howarth, D.F. Boesch, S.P. Seitzinger, K.E. Havens, C. Lancelot, and G.E. Likens. 2009. Controlling eutrophication: Nitrogen and phosphorus. Science $80: 323$.

Copes, W.E., H. Zhang, P.A. Richardson, B.E. Belayneh, A. Ristvey, J. Lea-Cox, and C. Hong. 2017. Nutrient, pH, alkalinity, and ionic property levels in runoff containment basins in Alabama, Louisiana, Maryland, Mississippi, and Virginia ornamental plant nurseries. HortScience 52:641-648. 
Deer, H. 2004. Pesticide adsorption and half-life. 8 May 2019. <https://extension. usu.edu/waterquality/files-ou/Agricultureand-Water-Quality/Pest/FactSheet151. pdf>.

Dias, M.C. 2012. Phytotoxicity: An overview of the physiological responses of plants exposed to fungicides. J. Bot. 2012:1-4.

Dubey, K.K. and M.H. Fulekar. 2011. Effect of pesticides on the seed germination of Cenchrus setigerus and pennisetum pedicellatum as monocropping and cocropping system: Implications for rhizospheric bioremediation. Rom. Biotechnol. Lett. 16:5909-5918.

Duke, S.O. and F.E. Dayan. 2015. Discovery of new herbicide modes of action with natural phytotoxins, p. 79-92. In: P. Maienfisch and T.M. Stevenson (eds.). Discovery and synthesis of crop protection products. Amer. Chem. Soc. Symp. Ser. 1204. Amer. Chem. Soc., Washington, DC.

Escolà Casas, M. and K. Bester. 2015. Can those organic micro-pollutants that are recalcitrant in activated sludge treatment be removed from wastewater by biofilm reactors (slow sand filters)? Sci. Total Environ. 506-507:315-322.

Fain, G.B., C.H. Gilliam, K.M. Tilt, J.W. Olive, and B. Wallace. 2000. Survey of best management practices in container production nurseries. J. Environ. Hort. 18:142-144.

Fernandez, R.T., T. Whitwell, M.B. Riley, and C.R. Bernard. 1999. Evaluating semiaquatic herbaceous perennials for use in herbicide phytoremediation. J. Amer. Soc. Hort. Sci. 124:539-544.

Fidalgo, F., I. Santos, and R. Salema. 1993. Effects of deltamethrin on field grown potato plants: Biochemical and ultrastructural aspects. Ann. Bot. 72:263267.

Fischer, G., F.N. Tubiello, H. van Velthuizen, and D.A. Wiberg. 2007. Climate change impacts on irrigation water requirements: Effects of mitigation, 19902080. Technol. Forecast. Soc. Change 74:1083-1107.

Food and Agriculture Organization of the United Nations. 2014. Water withdrawn by sector, around 2007. 5 Nov. 2018. <http:// www.fao.org/nr/water/aquastat/water_ use/index.stm\#mapshttp://www.fao.org/ $\mathrm{nr} /$ aquastat $>$.

Fulcher, A., A.V. LeBude, J.S. Owen, S.A. White, and R.C. Beeson. 2016. The next ten years: Strategic vision of water resources for nursery producers. HortTechnology 26:121-132.
Getter, K. 2015. Plant phytotoxicity in the greenhouse. 8 May 2019. <https:// www.canr.msu.edu/news/plant_ phytotoxicity_in_the_greenhouse $>$.

Ghimire, S.R., P.A. Richardson, P. Kong, J. Hu, J.D. Lea-Cox, D.S. Ross, G.W. Moorman, and C. Hong. 2011. Distribution and diversity of Phytophthora species in nursery irrigation reservoir adopting water recycling system during winter months. J. Phytopathol. 159:713719.

Gilliam, C.D., D.C. Fare, and A. Beasley. 1992. Nontarget herbicide losses from application of granular ronstar to container nurseries. J. Environ. Hort. 10:175-176.

Gilliom, R.J., J.E. Barbash, C.G. Crawford, P.A. Hamilton, J.D. Martin, N. Nakagaki, L.H. Nowell, J.C. Scott, P.E. Stackelberg, G.P. Thelin, and D.M. Wolock. 2006. Pesticides in the nation's streams and groundwater, 1992-2001. U.S. Geol. Surv. Circ. 1291.

Gisele, S., T. Yeager, and D. Haman. 2006. Survey of container nursery irrigation practices in west-central Florida: An educational opportunity. HortTechnology 16:682-685.

Goodwin, P.B. and S. Beach. 2001. Oxadiazon, oryzalin, and oxyfluorfen residues in container plant nurseries. HortScience 36:900-904.

Grant, G.A., P.R. Fisher, J.E. Barrett, and P.C. Wilson. 2019. Removal of agrichemicals from water using granular activated carbon filtration. Water Air Soil Pollut. 230:7.

Grossmann, K. 2007. Auxin herbicide action: Lifting the veil step by step. Plant Signal. Behav. 2:421-423.

Grossmann, K. 2010. Auxin herbicides: Current status of mechanism and mode of action. Pest Mgt. Sci. 66:113-120.

Hedegaard, M.J. and H.J. Albrechtsen. 2014. Microbial pesticide removal in rapid sand filters for drinking water treatment - Potential and kinetics. Water Res. 48:71-81.

Hedegaard, M.J. and H.J. Albrechtsen. 2015. Removal of pesticides with filter sand from biological rapid sand filters. IWA Specialized Conf. Biofilms in Drinking Water Systems from Treatment to Tap. p. 236-237. 8 May 2019. <http://orbit.dtu. $\mathrm{dk} /$ files/116665774/Removal_of pesticides_with_filter_sand_from_ biological_rapid_sand_filters.pdf>.

Hetrick, J., R.J. Pisigan, E. Behl, and C. Peck. 2011. Incorporation of water treatment effects on pesticide removal and transformations in drinking water exposure assessments. 8 May 2019. <https://www. epa.gov/pesticide-science-and-assessingpesticide-risks / finalization-guidanceincorporation-water-treatment\#_2_3_c_2>.

Johnson, T. 2013. 10 cities that could run out of water. 8 May 2019. <https:// weather.com/science/environment/news/ 10-cities-could-run-out-water-20131212/ $\# / 3>$.

Junker, C., P. Goff, S. Wagner, S. Werres, F. Biological, and F. Jki. 2016. Occurrence of Phytophthora species in commercial nursery production. Plant Health Prog. 17:64-75.

Jursik, M., K. Hamouzova, J. Andr, and J. Soukup. 2013. Effect of different adjuvants on phytotoxicity of flumioxazin to sunflower in different growth stages. Rom. Agr. Res. 30:335-372.

Jusoh, A., W.J.H. Hartini, N. Ali, and A. Endut. 2011. Study on the removal of pesticide in agricultural run off by granular activated carbon. Bioresour. Technol. 102:5312-5318.

Kabashima, J.N., S.J. Lee, D.L. Haver, K.S. Goh, L.S. Wu, and J. Gan. 2004. Pesticide runoff and mitigation at a commercial nursery site, p. 213-230. In: J.J. Gan, P.C Zhu, S.D. Aust, and A.T. Lemley (eds.). Pesticide decontamination and detoxification. Amer. Chem. Soc. Symp. Ser. 863. Amer. Chem. Soc., Washington, DC.

Keese, R.J., N.D. Camper, T. Whitwell, M.B. Riley, and P.C. Wilson. 1994. Herbicide runoff from ornamental container nurseries. J. Environ. Qual. $23: 320-324$.

Kong, P. and P.A. Richardson. 2004. Pythium and recycled irrigation water. 8 May 2019. <http://gpnmag.com/wpcontent/uploads/p32Nameth.pdf $>$.

Lambreva, M.D., D. Russo, F. Polticelli, V. Scognamiglio, A. Antonacci, V. Zobnina, G. Campi, and G. Rea. 2014. Structure/function/dynamics of photosystem II plastoquinone binding sites. Curr. Protein Pept. Sci. 15:285-295.

Lee, H.J. and S.O. Duke. 1994. Protoporphyrinogen ix-oxidizing activities involved in the mode of action of peroxidizing herbicides. J. Agr. Food Chem. 42:2610-2618.

Leistra, M., J.H. Smelt, J. Hilbrand Weststrate, F. Van Den Berg, and R. Aalderink. 2006. Volatilization of the pesticides chlorpyrifos and fenpropimorph from a potato crop. Environ. Sci. Technol. 40:96-102.

Lin, L., Z.-Q. Deng, and D.D. Gang. 2009. Nonpoint source pollution. Water Environ. Res. 81:1996-2018. 
Lin, S.C., B.R. Funke, and J.T. Schulz. 1972. Effects of some organophosphate and carbamate insecticide on nitrification and legume growth. Plant Soil 37:489496.

Lu, J., L. Wu, J. Newman, B. Faber, and J. Gan. 2006a. Degradation of pesticides in nursery recycling pond waters. J. Agr. Food Chem. 54:2658-2663.

Lu, J., L. Wu, J. Newman, B. Faber, D.J. Merhaut, and J. Gan. 2006b. Sorption and degradation of pesticides in nursery recycling ponds. J. Environ. Qual. 35:1795-1802.

MacDonald, J.D. 1994. Occurrence of Phytophthora species in recirculated nursery irrigation effluents. Plant Dis. 78:607611

Mack, R., J.S. Owen, A.X. Niemiera, and J. Latimer. 2017. Virginia nursery and greenhouse grower survey of best management practices. HortTechnology 27:386-392.

Mahnken, G.E., W.A. Skroch, R.B. Leidy, and T.J. Sheets. 1999. Metolachlor and simazine in surface runoff water from a simulated container plant nursery. Weed Technol. 13:799-806.

Majsztrik, J.C., R.T. Fernandez, P.R. Fisher, D.R. Hitchcock, J. Lea-Cox, J.S. Owen, L.R. Oki, and S.A. White. 2017. Water use and treatment in containergrown specialty crop production: A review. Water Air Soil Pollut. 228:151.

Mangiafico, S.S., J. Gan, L. Wu, J. Lu, J.P. Newman, B. Faber, D.J. Merhaut, and R. Evans. 2008. Detention and recycling basins for managing nutrient and pesticide runoff from nurseries. HortScience 43:393-398.

Mangiafico, S.S., J. Newman, D.J. Merhaut, J. Gan, B. Faber, and L. Wu. 2009. Nutrients and pesticides in stormwater runoff and soil water in production nurseries and citrus and avocado groves in California. HortTechnology 19:360 367.

Mangiafico, S.S., J. Newman, M. Mochizuki, D. Zurawski, D.J. Merhaut, and B. Faber. 2010. Nurseries surveyed in southern California adopt best practices for water quality. Calif. Agr. 64(1):26-30.

Martìn-Gullón, I. and R. Font. 2001. Dynamic pesticide removal with activated carbon fibers. Water Res. 35:516-520.

Mathers, H., L. Case, M. Bigger, P. Gordon, and L. Giese. 2012. Yearly research summary report 2012 ornamental research. 8 May 2019. <https://www. mathersenvironmental.com/wp-content/ uploads/2016/06/Research-Summary2012.pdf $>$.
Mathers, H.M., T.H. Yeager, and L.T. Case. 2005. Improving irrigation water use in container nurseries. HortTechnology $15: 8-12$.

Matthes, B., J. Schmalfuß, and P. Böger. 1998. Chloroacetamide mode of action, II: Inhibition of very long chain fatty acid synthesis in higher plants. Verlag der Zeitschrift für Naturforschung. 53c:1004-1011.

Maupin, M.A. 2018. Summary of estimated water use in the united states in 2015. U.S. Geological Survey Fact Sheet 2018-3035. 8 May 2019. <https://doi. org/10.3133/fs20183035>.

Meador, D.P., P.R. Fisher, P.F. Harmon, N.A. Peres, M. Teplitski, and C.L. Guy. 2012. Survey of physical, chemical, and microbial water quality in greenhouse and nursery irrigation water. Hort Technology 22:778-786.

Meikle, R.W., N.H. Kurihara, and D.H. Devries. 1983. Chlorpyrifos: The photodecomposition rates in dilute aqueous solution and on a surface, and the volatilization rate from a surface. Arch. Environ. Contam. Toxicol. 12:189-193.

Million, J., T. Yeager, and J. Albano. 2007. Consequences of excessive overhead irrigation on runoff during container production of sweet viburnum. J. Environ. Hort. 25:117-125.

Mishra, V., G. Srivastava, S.M. Prasad, and G. Abraham. 2008. Growth, photosynthetic pigments and photosynthetic activity during seedling stage of cowpea (Vigna unguiculata) in response to UV-B and dimethoate. Pestic. Biochem. Physiol. 92:30-37.

Moorman, G.W. 2011. Phytotoxicity. 8 May 2019. <https://extension.psu.edu/ phytotoxicity>.

Nakajima, Y., S. Yoshida, and T.A. Ono. 1996. Differential effects of urea/triazine-type and phenol-type photosystem II inhibitors on inactivation of the electron transport and degradation of the Dl protein during photoinhibition. Plant Cell Physiol. 37:673-680.

Nason, M.A., J. Farrar, and D. Bartlett. 2007. Strobilurin fungicides induce changes in photosynthetic gas exchange that do not improve water use efficiency of plants grown under conditions of water stress. Pest Mgt. Sci. 63:1191-1200.

National Pesticide Information Center. 2019. NPIC: National Pesticide Information Center. 13 Mar. 2019 $<$ http://npic.orst.edu/>.

Newman, J. 2010. Manage runoff with vegetated buffers. 8 May 2019. <https:// www.nurserymag.com/article/nmpro0210-vegetated-buffers/>.

National Oceanic and Atmospheric Administration. 2017. What is eutrophication? 8 May 2019. <https//oceanservice. noaa.gov/facts/eutrophication.html>.

Otto, S., S.E. Pappalardo, A. Cardinali, R. Masin, G. Zanin, and M. Borin. 2016. Vegetated ditches for the mitigation of pesticides runoff in the Po Valley. PLoS One 11:e0153287.

Parke, J., C. Lewis, and N. Grunwald. 2008. Tracing the path of pathogens. 8 May 2019. <https://naldc.nal.usda.gov/ download/38588/PDF>.

Parke, J.L., N. Redekar, J. Eberhart, and F. Funahashi. 2019. Hazard analysis for Phytophthora species in nurseries: Three case studies. HortTechnology (In Press).

Parween, T., S. Jan, and T. Fatma. 201la. Alteration in nitrogen metabolism and plant growth during different developmental stages of green gram (Vigna radiata L.) in response to chlorpyrifos. Acta Physiol. Plant. 33:2321-2328.

Parween, T., S. Jan, and T. Fatma. 2012. Evaluation of oxidative stress in Vigna radiata $\mathrm{L}$. in response to chlorpyrifos. Intl. J. Environ. Sci. Technol. 9:605-612.

Parween, T., S. Jan, S. Mahmooduzzafar, and T. Fatma. 2011b. Assessing the impact of chlorpyrifos on growth, photosynthetic pigments and yield in Vigna radiata L. at different phenological stages. Afr. J. Agr. Res. 6:4432-4440.

Parween, T., S. Jan, S. Mahmooduzzafar, T. Fatma, and Z.H. Siddiqui. 2016. Selective effect of pesticides on plant - A review. Crit. Rev. Food Sci. Nutr. 56:160-179.

Petit, A.N., F. Fontaine, P. Vatsa, C. Clément, and N. Vaillant-Gaveau. 2012. Fungicide impacts on photosynthesis in crop plants. Photosynth. Res. 111:315326.

Pitton, B.J.L., C.R. Hall, D.L. Haver, S.A. White, and L.R. Oki. 2018. A cost analysis for using recycled irrigation runoff water in container nursery production: A southern California nursery case study. Irr. Sci. 36:217-226.

Poe, S.L. 1970. Evaluations of pesticides for phytotoxicity on chrysanthemum flowers. Florida Agr. Expt. Sta. J. 3702:469-471.

Pottorff, L.P. and K.L. Panter. 1997. Survey of Pythium and Phytophthora spp. in irrigation water used by Colorado commercial greenhouses. HortTechnology 7:153-155. 
Poudyal, S., B.M. Cregg, and T.R. Fernandez. 2018. Overcoming barriers to use of nursery run-off water: Understanding plant sensitivity to residual pesticides. HortScience 53(9S):124. (Abstr.).

Prasad, S.M., A. Singh, and P. Singh. 2015. Physiological, biochemical and growth responses of Azolla pinnata to chlorpyrifos and cypermethrin pesticides exposure: A comparative study. Chem. Ecol. 31:285-298.

Prather, T.S., J.M. Ditomaso, and J.S. Holt. 2000. Herbicide resistance: Definition and management strategies. Univ. California. Div. Agr. Natl. Resources Publ. 8012. 8 May 2019. <https:// anrcatalog.ucanr.edu/pdf/8012.pdf>.

Rajagopalan, B., K. Nowak, J. Prairie, M. Hoerling, B. Harding, J. Barsugli, A. Ray, and B. Udall. 2009. Water supply risk on the Colorado River: Can management mitigate? Water Resour. Res. 45:W08201.

Reade, J.P.H. and A.H. Cobb. 2002. Herbicides: Modes of action and metabolism, p. 134-170. In: R.E.L. Naylor (ed.). Weed management handbook. Blackwell Sci., Oxford, UK.

Regan, R. and R. Ticknor. 1987. Application of isoxaben and pendimethalin to container-grown broadleaved evergreen shrubs. Ornamentals Northwest Arch. 11(1):12.

Richardson, F.E. 1972. Critical growth stages for 2,4-D phytotoxicity to sugarcane. Proc. South African Sugar Technologists'. Assn. 6:168-175.

Riley, M.B. 2003. Herbicide losses in runoff of containerized plant production nurseries. HortTechnology 13:16-21.

Riley, M.B., R.J. Keese, N.D. Camper, T. Whitwell, and P.C. Chris. 1994. Pendimethalin and oxyfluorfen residues in pond water and sediment from container. Weed Technol. 8:299-303.

Robbins, J. and J. Boyd. 2011. Weed control in container nurseries. Univ. Arkansas, Div. Agr. FSA6123. 8 May 2019. <https:// www.uaex.edu/publications/PDF/FSA6123.pdfs.

Roseth, R. and K. Haarstad. 2010. Pesticide runoff from greenhouse production. Water Sci. Technol. 61:1373-1381.

Ross, M.A. and D.J. Childs. 1996. Herbicide mode-of-action summary. 8 May 2019. <https://www.extension.purdue. edu/extmedia/ws/ws-23-w.html>.

Rózsavölgyi, T. and F. Horváth. 2008. Effect of pyrethroid insecticides on the photosynthetic activity of pea mesophyll protoplasts. Acta Biol. Szeged. 52:233235.
Saladin, G., C. Magné, and C. Clément. 2003. Effects of fludioxonil and pyrimethanil, two fungicides used against Botrytis cinerea, on carbohydrate physiology in Vitis vinifera L. Pest Mgt. Sci. 59:1083-1092.

Samuelsen, E.D., N. Badawi, O. Nybroe, S.R. Sørensen, and J. Aamand. 2017. Adhesion to sand and ability to mineralise low pesticide concentrations are required for efficient bioaugmentation of flowthrough sand filters. Appl. Microbiol. Biotechnol. 101:411-421.

Sandmann, G., P.M. Bramley, and P. Böger. 1980. The inhibitory mode of action of the pyridazinone herbicide norflurazon on a cell-free carotenogenic enzyme system. Pestic. Biochem. Physiol. 14:185-191.

Schmalfuß, J., B. Matthes, P. Mayer, and P. Böger. 1998. Chloroacetamide mode of action, I: Inhibition of very long chain fatty acid synthesis in Scenedesmus acutus. Zeitschrift für Naturforschung 53c:9951003.

Shaner, D. 2006. An overview of glyphosate mode of action: Why is it such a great herbicide? North Central Weed Sci. Soc. Proc. 61:94.

Shipitalo, M.J., J.V. Bonta, E.A. Dayton, and L.B. Owens. 2010. Impact of grassed waterways and compost filter socks on the quality of surface runoff from corn fields. J. Environ. Qual. 39:1009-1018.

Southern Nursery Association. 2013. Best management practices: Guide for producing nursery crops. 3.0. 29 Mar. 2019. <https://www.sna.org/page-1140025>.

Spiers, J.D., T. Davies, C. He, K.M. Heinz, C.E. Bogran, and T.W. Starman. 2008. Do insecticide affect plant growth and development? Greenhouse Grower. 26(2). 15 May 2019. <https://pdfs.semanticscholar. org/2b86/2f8218e2ac0d92496f22359al d2ae50f8b06.pdf>.

Staats, D., D. Hillock, and J.E. Klett. 1998. Weed control and phytotoxicity of preemergence herbicides applied to container-grown herbaceous plant. HortTechnology 8:325-328.

Stearman, G.K., D.B. George, K. Carlson, and S. Lansford. 2003. Pesticide removal from container nursery runoff in constructed wetland cells. J. Environ. Qual. 32:1548-1556.

Stevens, M.M., R.F. Reinke, N.E. Coombes, S. Helliwell, and J. Mo. 2008. Influence of imidacloprid seed treatments on rice germination and early seedling growth. Pest Mgt. Sci. 64:215-222.

Straw, N.A., N.J. Fielding, and A. Walters. 1996. Phytotoxicity of insecticides used to control aphids on sitka spruce, Picea sitchensis (Bong.). Carr. Crop Protection $15: 451-459$.

Tjosvold, S., D. Chambers, and S. Koike. 2005. Evaluation of fungicides for the control of Phytophthora ramorum infecting rhododendron, camellia, viburnum and pieris. 8 May 2019. <https://www.fs.fed.us/psw/ publications/documents/psw_gtr196/ psw_gtr196_005_042Tjosvold.pdf $>$.

University of Wisconsin. 2013. Corn and soybean herbicide chart. 8 May 2019. <http://www. soybeanresearchinfo. com/pdf_docs/weeds_herbicide_MOA. $\mathrm{pdf}>$.

Untiedt, R. and M.M. Blanke. 2004. Effects of fungicide and insecticide mixtures on apple tree canopy photosynthesis, dark respiration and carbon economy. Crop Prot. 23:1001-1006.

U.S. Department of Agriculture. 2016. U.S. Horticulture in 2014: Results from the 2014 census of horticultural specialties. ACH1233. 15 May 2019. <https://www.nass.usda. gov/Publications/Highlights/2016/ Census_of_Horticulture_Highlights.pdf $>$.

Van Assche, F. and H. Clijsters. 1990. Effects of metals on enzyme activity in plants. Plant Cell Environ. 13:195-206.

Vea, E. and C. Palmer. 2017a. IR-4 Ornamental horticulture program powdery mildew efficacy. 8 May 2019. <http://www. ir4project.org/about-environmentalhorticulture/environmental-horticultureresearch-summaries $>$.

Vea, E. and C. Palmer. 2017b. IR-4 Ornamental horticulture program isoxaben crop safety. 8 May 2019. <http://ir4.rutgers. edu/Ornamental/SummaryReports/ IsoxabenDataSummary2017.pdf $>$.

Vilsack, T. and J.T. Reilly. 2013. 2012 Census of agriculture. Farm and ranch irrigation survey. 8 May 2019. <https:// www.nass.usda.gov/Publications / AgCensus/2012/Online_Resources / Farm_and_Ranch_Irrigation_Survey/ fris13.pdf $>$.

Vinit-Dunand, F., D. Epron, B. AlaouiSossé, and P.M. Badot. 2002. Effects of copper on growth and on photosynthesis of mature and expanding leaves in $\mathrm{cu}^{-}$ cumber plants. Plant Sci. 163:53-58.

Vymazal, J. and T. Březinová. 2015. The use of constructed wetlands for removal of pesticides from agricultural runoff and drainage: A review. Environ. Intl. 75:11-20.

Warsaw, A.L., R.T. Fernandez, B.M. Cregg, and J.A. Andresen. 2009. Container-grown ornamental plant growth and water runoff nutrient content and volume under four irrigation treatments. HortScience 44:1573-1580. 
Warsaw, A.L., R. Thomas Fernandez, D.R. Kort, B.M. Cregg, B. Rowe, and C. Vandervoort. 2012. Remediation of metalaxyl, trifluralin, and nitrate from nursery runoff using container-grown woody ornamentals and phytoremediation areas. Ecol. Eng. 47:254-263.

Wauchope, R.D., S. Yeh, J.B.H.J. Linders, R. Kloskowski, K. Tanaka, B. Rubin, A. Katayama, W. Kördel, Z. Gerstl, M. Lane, and J.B. Unsworth. 2002. Pesticide soil sorption parameters: Theory, measurement, uses, limitations and reliability. Pest Mgt. Sci. 58:419-445.

Werres, S., S. Wanger, T. Brand, K. Kaminski, and D. Seipp. 2007. Survival of Phytophthora ramorum in recirculating irrigation water and subsequent infection of rhododendron and viburnum. Plant Dis. 91:1034-1044.

White, S., J. Owen, Jr., J. Majsztrik, T. Fernandez, P. Fisher, C. Hall, T. Irani, J.D. Lea-Cox, J.P. Newman, and L. Oki. 2013. Grower identified priorities for water research in ornamental crops.
Southern Nursery Assn. Res. Conf. 57:299-301.

Will, E. and J.E. Faust. 2010. Irrigation water quality for greenhouse production. Univ. Tennessee Agr. Ext. Serv. PB 1617.

Wilson, S.K. and S. von Broembsen. 2015. Capturing and recycling irrigation runoff as a pollution prevention measure. Oklahoma State Univ. Ext. BAE-1518. 8 May 2019. <http://pods.dasnr.okstate.edu/ docushare/dsweb/Get/Document7408/BAE-1518web.pdf>.

Wilson, C., P. Strimple, S. Wilson, and J. Albano. 2005. Nontarget deposition of methiocarb applied to a foliage plant staging area. Bull. Environ. Contam. Toxicol. 74:509-517.

Wilson, P.C., T. Whitwell, and M.B. Riley. 1995. Effects of ground cover and formulation on herbicides in runoff water from miniature nursery sites. Weed Sci. 43:671-677.

Wilson, C., T. Whitwell, and M.B. Riley. 1996. Detection and dissipation of iso- xaben and trifluralin in containerized plant nursery runoff water. Weed Sci. 44:683-688.

Wines, M. 2014. Colorado river drought forces a painful reckoning for states. 29 Mar. 2019. <http://www.nytimes.com/2014/ 01/06/us/colorado-river-drought-forcesa-painful-reckoning-for-states.html?_r $=0$ \& pagewanted $=$ print $>$.

World Economic Forum. 2015. Global risks 2015. 8 May 2019. <http://www3. weforum.org/docs/WEF_Global_Risks_ 2015_Report15.pdf>.

Xia, X.J., Y.Y. Huang, L. Wang, L.F. Huang, Y.L. Yu, Y.H. Zhou, and J.Q. Yu. 2006. Pesticides-induced depression of photosynthesis was alleviated by 24-epibrassinolide pretreatment in Cucumis sativus L. Pestic. Biochem. Physiol. 86:42-48.

Zhang, H. and C. Hong. 2017. The $\mathrm{pH}$ factor. 8 Nov. 2018. <http://magazine. nurserymag.com/article/june-2017/ the-ph-factor.aspx>. 